\title{
Making light work of indoor gardening
}

\section{LEDの光で屋內ガーデニング}

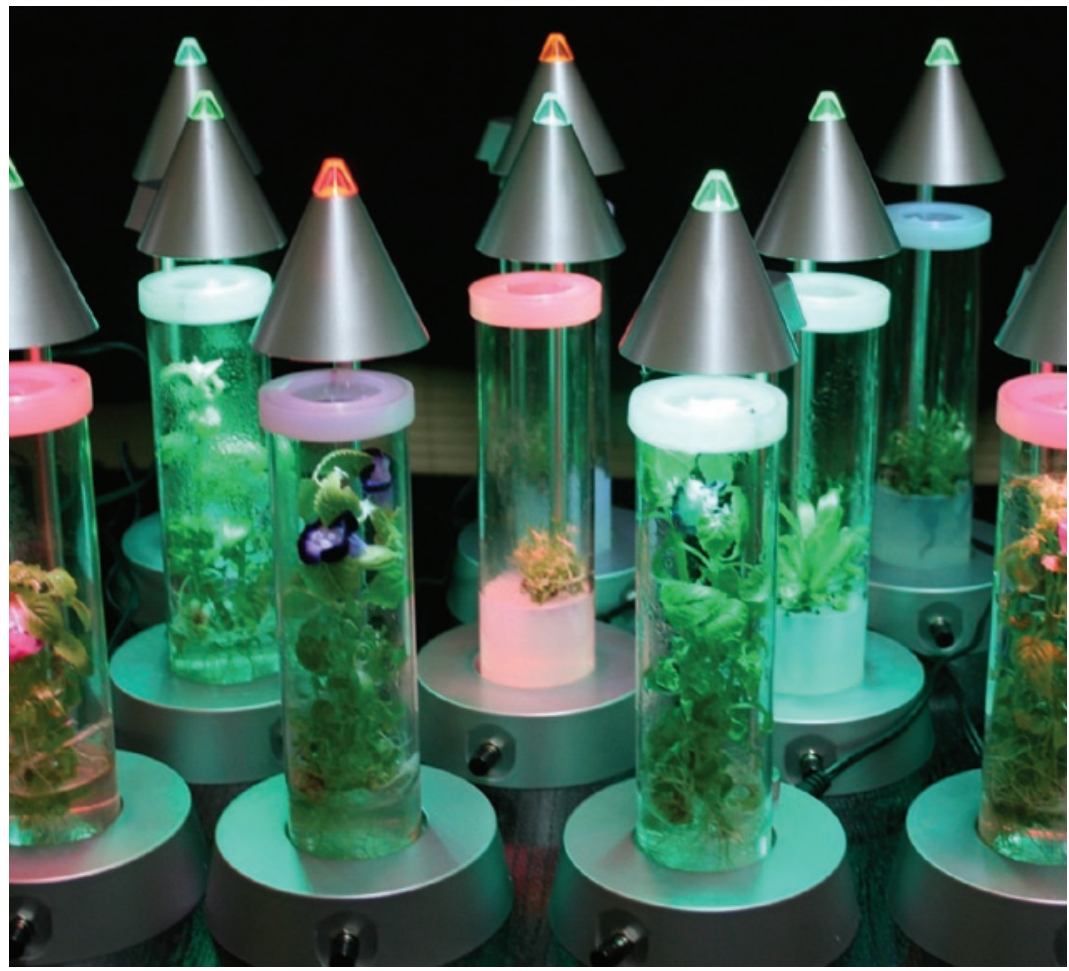

この奇妙な植物たちは、いちども日 の光を浴びたことがない。密閉され たガラス容器の中には窒素とリン酸が 計算された比率で配合されており、強 い光が当たると、このバランスが崩れ て植物は開花できなくなってしまう。 これらのデザイナーフラワーは、発光 ダイオード（LED）を唯一の光エネル ギー源としているのである。

東京に本社がある自動車用照明器 具メ一カーのスタンレー電気は、東海 大学 (神奈川県) の森康裕と協同して この培養技術を開発し、これまでにバ ラとトレニアを作り出した。LEDの青、 赤、緑の光の最適な照射量を特定する には 5 年の歳月を要した。スタンレー 電気は、ほとんど場所をとらず、手も かからないこの植物を、今年の春に市 場に出すことを計画している。 